University of Nebraska - Lincoln

DigitalCommons@University of Nebraska - Lincoln

Faculty Publications: Department of

Entomology

Entomology, Department of

2007

\title{
Economic Threshold for Soybean Aphid (Hemiptera: Aphididae)
}

D. W. Ragsdale

University of Minnesota, ragsd001@umn.edu

B. P. McCornack

University of Minnesota

R. C. Venette

U.S. Forest Service

B. D. Potter

University of Minnesota

I. V. Macrae

University of Minnesota

See next page for additional authors

Follow this and additional works at: https://digitalcommons.unl.edu/entomologyfacpub

Part of the Entomology Commons

Ragsdale, D. W.; McCornack, B. P.; Venette, R. C.; Potter, B. D.; Macrae, I. V.; Hodgson, E. W.; O'Neal, M. E.; Johnson, K. D.; O'Neil, R. J.; Difonzo, C. D.; Hunt, Thomas E.; Glogoza, P. A.; and Cullen, E. M., "Economic Threshold for Soybean Aphid (Hemiptera: Aphididae)" (2007). Faculty Publications: Department of Entomology. 297.

https://digitalcommons.unl.edu/entomologyfacpub/297

This Article is brought to you for free and open access by the Entomology, Department of at DigitalCommons@University of Nebraska - Lincoln. It has been accepted for inclusion in Faculty Publications: Department of Entomology by an authorized administrator of DigitalCommons@University of Nebraska - Lincoln. 


\section{Authors}

D. W. Ragsdale, B. P. McCornack, R. C. Venette, B. D. Potter, I. V. Macrae, E. W. Hodgson, M. E. O'Neal, K. D. Johnson, R. J. O'Neil, C. D. Difonzo, Thomas E. Hunt, P. A. Glogoza, and E. M. Cullen 


\title{
Economic Threshold for Soybean Aphid (Hemiptera: Aphididae)
}

\author{
D. W. RAgSDale, ${ }^{1}$ B. P. McCORnaCK, R. C. VEnetTe, ${ }^{2}$ B. D. POTTER, ${ }^{3}$ I. V. MACRAE, \\ E. W. HODGSON, M. E. O’NEAL ${ }^{4}$ K. D. JOHNSON, ${ }^{4}$ R. J. O'NEIL, ${ }^{5}$ C. D. DIFONZO, ${ }^{6}$ \\ T. E. HUNT, ${ }^{7}$ P. A. GLOGOZA, ${ }^{8}$ AND E. M. CULLEN ${ }^{9}$
}

Department of Entomology, University of Minnesota, 219 Hodson Hall, 1980 Folwell Avenue, St. Paul, MN 55108

\begin{abstract}
J. Econ. Entomol. 100(4): 1258-1267 (2007)
ABSTRACT Soybean aphid, Aphis glycines Matsumura (Hemiptera: Aphididae), reached damaging levels in 2003 and 2005 in soybean, Glycine $\max$ (L.) Merrill, in most northern U.S. states and Canadian provinces, and it has become one of the most important pests of soybean throughout the North Central region. A common experimental protocol was adopted by participants in six states who provided data from 19 yield-loss experiments conducted over a 3-yr period. Population doubling times for field populations of soybean aphid averaged $6.8 \mathrm{~d} \pm 0.8 \mathrm{~d}$ (mean \pm SEM). The average economic threshold (ET) over all control costs, market values, and yield was $273 \pm 38$ (mean $\pm 95 \%$ confidence interval [CI], range 111-567) aphids per plant. This ET provides a 7-d lead time before aphid populations are expected to exceed the economic injury level (EIL) of $674 \pm 95$ (mean $\pm 95 \%$ CI, range 275-1,399) aphids per plant. Peak aphid density in 18 of the 19 location-years occurred during soybean growth stages R3 (beginning pod formation) to R5 (full size pod) with a single data set having aphid populations peaking at R6 (full size green seed). The ET developed here is strongly supported through soybean growth stage R5. Setting an ET at lower aphid densities increases the risk to producers by treating an aphid population that is growing too slowly to exceed the EIL in $7 \mathrm{~d}$, eliminates generalist predators, and exposes a larger portion of the soybean aphid population to selection by insecticides, which could lead to development of insecticide resistance.
\end{abstract}

KEY WORDS yield loss, population dynamics, invasive species

The soybean aphid, Aphis glycines Matsumura (Hemiptera: Aphididae), is native to Asia, and it has caused substantial damage to soybean, Glycine max (L.) Merr., in North America since its confirmed occurrence in August 2000 (Ragsdale et al. 2004). At present, the soybean aphid is the most significant insect threat to soybean production in North America. In China and in other parts of Asia, this insect is only an occasional pest of soybean, and when plants are colonized by soybean aphid in early vegetative growth stage, yield loss in excess of 50\% can occur (Wang et

\footnotetext{
${ }^{1}$ Corresponding author, e-mail: ragsd001@umn.edu.

${ }^{2}$ U.S. Forest Service, North Central Research Station, 1561 Lindig Ave., St. Paul, MN 55108.

${ }^{3}$ Southwest Research \& Outreach Center, University of Minnesota, Lamberton, MN 56152.

${ }^{4}$ Department of Entomology, Iowa State University, Ames, IA 50011.

${ }^{5}$ Department of Entomology, Purdue University, 901 W. State St. West Lafayette, IN 47907.

${ }^{6}$ Department of Entomology, Michigan State University, 243 Natural Science Bldg., East Lansing, MI 48824.

${ }^{7}$ Department of Entomology, University of Nebraska-Lincoln, Haskell Agricultural Laboratory, 57905866 Rd., Concord, NE 68728.

${ }^{8}$ University of Minnesota, Regional Extension Center-Moorhead, 715 11th St. N, Suite 107C Moorhead, MN 56560.

${ }^{9}$ Department of Entomology, 536 Russell Labs, University of Wisconsin-Madison, 1630 Linden Dr., Madison, WI 53706.
}

al. 1994). In Minnesota, soybean aphid outbreaks are associated with a reduction in plant height, pod number, seed size and quality, and yield (Ostlie 2001). The damage potential at low-to-moderate aphid densities is less clear, but soybean aphid feeding is known to disrupt the photosynthetic processes at relatively low aphid densities (Macedo et al. 2003). Soybean aphid is also a vector of numerous plant viruses (Clark and Perry 2002, Davis et al. 2005), which can further limit soybean yield and seed quality.

Aphid population declines in annual cropping systems are attributed to variable host plant quality (e.g., physiological age and antibiosis), increased activities of natural enemies, and weather extremes (van den Berg et al. 1997, Fox et al. 2004, Karley et al. 2004, Li et al. 2004). In controlled environments, soybean aphid populations can double in $1.5 \mathrm{~d}$ (McCornack et al. 2004), but these high intrinsic rates of increase are only obtainable under ideal conditions where population growth is not constrained by host quality, effects of weather, or natural enemies. Soybean aphid biology and the specific conditions that trigger rapid increases in population densities that are associated with yield reductions are not well understood in North America (Ragsdale et al. 2004). However, field estimates of soybean aphid population growth rates are less than 
the theoretical intrinsic rate of increase (Costamagna and Landis 2006). Therefore, basing an economic threshold (ET) on population doubling times derived from laboratory experiments that occurred in the absence of any environmental resistance will result in an artificially low economic threshold. Such an economic threshold based on laboratory derived intrinsic rate of increase has been calculated (Olson and Badibanga 2005a), resulting in a threshold of three aphids per plant, which in their model had the highest economic return. Such a threshold is not realistic, because it assumes that the multiple sources of environmental resistance would not prevent exponential growth of soybean aphid populations.

The objective of this study was to quantify the relationship between aphid densities and yield loss under field conditions in which biotic and abiotic factors were allowed to influence soybean aphid densities. These data were used to estimate the aphid density at which control measures should be applied to prevent yield losses. ETs and economic injury levels (EIL) were developed based on current expected yields, control costs, and market values for U.S. soybean.

\section{Materials and Methods}

Field Plot Design. In 2003, 2004, and 2005, a common experimental protocol was used at sites located in six states (Iowa, Michigan, Minnesota, Nebraska, North Dakota, and Wisconsin), so that comparisons could be made across locations and years (19 locationyears). At each location, a soybean variety was selected that was adapted for that area, and it was planted from mid- to late May (Table 1). Plots were $3.0 \mathrm{~m}$ in width (four rows) by $12.3 \mathrm{~m}$ in length with a $76.2-\mathrm{cm}$ (30-in.) row spacing. We used predetermined, targeted aphid population densities based on cumulative aphid-days (CAD) of $0,2,000,4,000,8,000$, $12,000,16,000$, and an untreated control (=maximum $\mathrm{CAD}$ ) as treatments. Cumulative aphid-days is a single value that provides a measure of aphid abundance over time, and it can be calculated weekly as sampling occurs. We calculated CAD by using the procedures outlined in Hanafi et al. (1989).

Insecticide treatments varied among locations and years and depended largely upon the natural level of aphid infestation in any given location-year. Each target aphid density was replicated a minimum of four times within each location-year, and treatments were arranged in a randomized block design. With the exception of one location-year in Minnesota in 2003 where the study was located in a commercial production field, fallow ground of $\approx 3 \mathrm{~m}$ surrounded each plot to facilitate application of insecticide to individual plots, minimize spray drift among plots, and encourage uniform aphid colonization throughout the experiment (DiFonzo et al. 1996, Hodgson et al. 2005). Soybean aphids were allowed to naturally colonize the field except in Nebraska in 2004 where soybean aphids were seeded into plots by using field-collected aphids from a nearby field. In the Nebraska plots, an expand- ing trifoliolate containing three to five aphids was excised and placed on approximately one plant per 30 $\mathrm{cm}$ of row within each plot on 23 July 2004 . The timing of this artificial infestation matched the general appearance and density of aphids in most Nebraska soybean fields. In all location-years, a foliar insecticide, lambda-cyhalothrin at 16.8-28.0 g (AI)/ ha (Warrior with Zeon Technology, Syngenta Crop Protection, Greensboro, NC), was applied to all plots in a given treatment by using ground equipment once a target aphid density in a treatment in terms of CAD was reached (averaged across all blocks). In all cases, insecticides were applied within $2 \mathrm{~d}$ after aphid counts were completed. If soybean aphid populations began to increase after the initial insecticide application, additional applications were applied to prevent aphid populations from increasing.

Aphid Sampling and Soybean Yield. Nondestructive whole-plant samples were taken to enumerate the total number of aphids per plant. To detect small populations early in the season, up to 20 plants per plot were inspected. As the season progressed and the frequency of encountering plants with aphids increased to $50 \%, 10$ plants per plot were sampled. When $>80 \%$ of plants were aphid infested, five plants were counted per plot at each sampling date. For analysis, all data were converted to mean number of aphids per plant per plot. Soybean growth stages (Fehr and Caviness 1977), whether vegetative or reproductive, were noted each week.

Yield was estimated by harvesting the entire middle two rows of each plot with a small-plot combine and adjusting seed moisture to $13 \%$. Linear regression (PROC REG; SAS Institute 2001) was then used to relate percentage yield reduction to $\mathrm{CAD}$; slope and intercept estimates were used in all EIL calculations.

Values Used in Calculation of an Economic Injury Level. Cost estimates for insecticide and application costs, market value, and expected yield were used to calculate an EIL for soybean aphid. A gain threshold (GT) expressed in percentage yield loss was calculated by estimating control costs $(\mathrm{C})$ [ $\$ /$ ha] divided by estimated market value (V) [ $\$ /$ ton] by using various yield potentials $(\mathrm{Y})$ [tons/ha] (Pedigo et al. 1986), which is equivalent to

$$
\mathrm{GT}(\% \text { yield loss })=\frac{\mathrm{C}}{\mathrm{V} \times \mathrm{Y}} \times 100
$$

Average retail price of representative insecticides registered for soybean aphid control and their associated application costs were obtained from an informal phone survey of multiple local elevators along with published sources (Dobbins et al. 2004, WASS 2004, Edwards and Smith 2005). Average soybean prices from 2000 to 2005 were obtained from the National Agriculture Statistical Services (NASS 2006). Finally, soybean yield potentials used in the calculation of the GT represent the range of long-term average soybean yield throughout the North Central growing region (NASS 2006). 


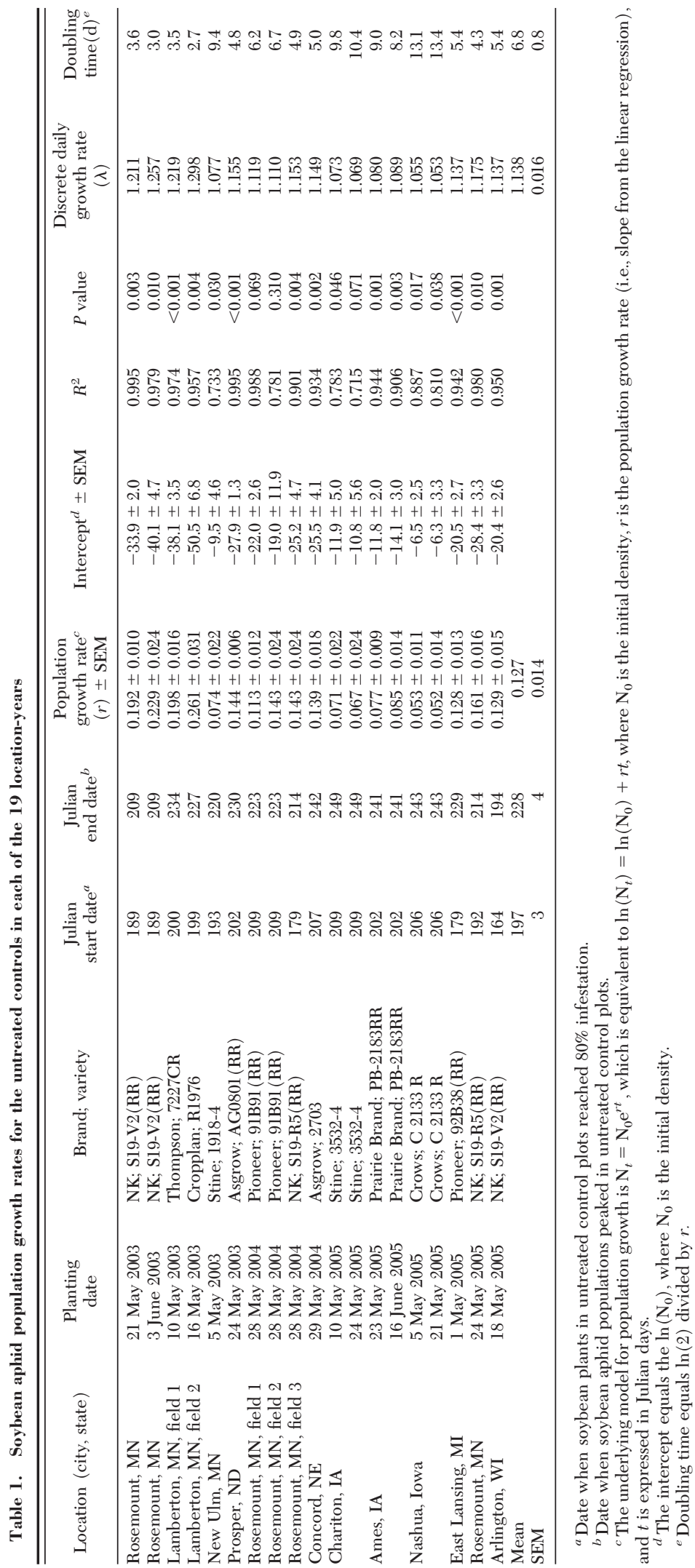


An EIL expressed in CAD was calculated using an adjusted percentage yield potential by subtracting the GT calculated in equation 1 from the maximum potential yield set at $100 \%$ and incorporating the y-intercept $\left(\beta_{0}\right)$ and slope $\left(\beta_{1}\right)$ parameters estimated from the linear regression of CAD against percentage yield loss and can be written as follows:

$$
\operatorname{EIL}(\mathrm{CAD})=\frac{\beta_{0}-(\% \text { yield potential })}{\beta_{1}}
$$

To convert the EIL expressed as CAD to an EIL based on aphid density (aphids per plant) at a particular point in time, we used the general formula for the summation of a geometric progression:

$$
s=\frac{l \lambda-a}{\lambda-1}
$$

where in our application, $s$ is the CAD on a per plant basis; $\lambda$ is the discrete time population growth rate $\left(\lambda=\mathrm{e}^{r}\right.$ with e being the base of the natural logarithm and $r$ being the population growth rate); $a$ is aphid density at the start of accumulation of aphid-days; and $l$ is aphid density on the last day of the series. In this case, $l$ is also the EIL but expressed as aphids per plant. For convenience we conservatively set $a=1$ under the assumption that the accumulation of aphid-days is insignificant until densities reach an average of one aphid per plant. We rearrange this equation to solve for $l$, which yields the following:

$$
l=\frac{s(\lambda-1)+1}{\lambda}
$$

In this equation, $s$ is equivalent to the EIL calculated from equation 2. Finally, to convert this EIL to an economic threshold, expressed in aphids per plant that crop managers will use, we calculated aphid densities $t$ days before reaching the EIL based on the equation $l \lambda^{-t}$. For our purposes we set $t$, or lead time, to $1,3,5$, and $7 \mathrm{~d}$. This ET also assumes that the aphid population is increasing and that crop managers will need anywhere from 1 to $7 \mathrm{~d}$ to make arrangements to have a foliar insecticide applied to a field. To solve for the number of $\mathrm{d}(t)$ it takes for a given aphid density to reach a specific EIL $(l)$ we can rearrange the equation used to calculate lead time,

$$
t=\frac{\ln (l / a)}{\ln (\lambda)}
$$

where $a$ is the initial aphid density and $\lambda$ is derived from the estimated population growth rates.

To estimate $\lambda$ used in equations 4 and 5 , we averaged the population growth rate $(r)$ from all 19 locationyears by using aphid population growth data from the untreated control plots where maximum CAD occurred. Aphid densities were natural log transformed and simple linear regression was used to estimate $r$ for each individual location-year. The population growth rate was calculated using aphid densities between the periods when aphid populations first reached $80 \%$ plant infestation and the point in time when peak aphid densities were observed. For this application, the underlying model for population growth is $\mathrm{N}_{t}=$ $\mathrm{N}_{0} \mathrm{e}^{r t}$, which is equivalent to $\ln \left(\mathrm{N}_{t}\right)=\ln \left(\mathrm{N}_{0}\right)+r t$, where $\mathrm{N}_{0}$ is the initial aphid density, $r$ is the population growth rate (i.e., slope from the linear regression), and $t$ is expressed in d (Julian days). Discrete daily growth rate $(\lambda)$ was calculated as $\mathrm{e}^{r}$, averaged across all location-years, and used in the calculation of all ETs.

\section{Results and Discussion}

Market Value and Control Costs Used in Calculation of the EIL. Application cost of using a personally owned, nonpropelled, boom sprayer was estimated at $\$ 5.09 /$ ha by Lazarus and Selley (2005). Their costs included fuel, lubricants, repairs, maintenance, labor, and power and implement depreciation, interest, insurance, and housing of equipment. Custom application costs for ground application in 2005 averaged $\$ 12.23 /$ ha (range, $\$ 8.65$ to $\$ 21.00 /$ ha) (Dobbins et al. 2004, WASS 2004, Edwards and Smith 2005). Custom aerial application costs in 2004 and 2005 averaged $\$ 14.85 /$ ha (ranged from $\$ 12.36$ to $\$ 16.68 / \mathrm{ha}$ ) (Dobbins et al. 2004; Edwards and Smith 2005). We obtained retail cost of commonly used insecticides for soybean aphid control that included pyrethroids (lambda-cyhalothrin; zeta-cypermethrin, or Mustang, FMC Corporation, Philadelphia, PA; and esfenvalerate or Asana XL, DuPont, Wilmington, DE) and an organophosphate (chlorpyrifos or Lorsban-4E, Dow AgroSciences LLC, Indianapolis, IN). Total control costs included the insecticide and its application, and we derived three estimates of soybean aphid control costs: 1) lowest application rate of $\$ 16.41 /$ ha ( $\$ 6.64 /$ acre) by using the lowest cost insecticide applied with grower-owned equipment, 2) a mid-range control cost of $\$ 24.51 /$ ha $(\$ 9.92 /$ acre $)$ that is representative of custom ground application of a moderately priced insecticide, and 3) a high control cost option at $\$ 32.94 /$ ha $(\$ 13.33 /$ acre), which represents a maximum labeled rate of an expensive insecticide custom applied by air (Table 2) .

Market values used in the calculation of the EIL represented three probable soybean prices for the North Central Region: 1) $\$ 202.09 /$ ton soybean ( $\$ 5.50 /$ $\mathrm{bu}$ ) as a conservative or lowest expected market price, 2) a mid-range market price of $\$ 220.46 /$ ton $(\$ 6.00 /$ bu), and 3) an optimistic soybean price of $\$ 238.83 /$ ton $(\$ 6.50 / \mathrm{bu})$. Our soybean price estimates are not a fine-tuned forecast for soybean prices, but rather we used these different values to assess the sensitivity of the soybean aphid EIL to fluctuating soybean prices and application costs (Barrigossi et al. 2003). Yield expectations used in calculating the EIL ranged from $2.02 \mathrm{ton} / \mathrm{ha}(30 \mathrm{bu} / \mathrm{acre})$ to $4.04 \mathrm{ton} / \mathrm{ha}(60 \mathrm{bu} / \mathrm{acre})$. These yield expectations represent a range of average yields reported for various states or regions within the United States (NASS 2006). Other economic factors that may affect some production systems also should be considered when estimating an ET, but they are too numerous to estimate here. For example, in narrow row soybean production systems, yield losses from 1 to $2.5 \%$ are caused by driving ground equipment through 
Table 2. Economic thresholds (ET) and economic injury levels (EIL) for soybean aphid with various control costs, market prices, and soybean yield potentials

\begin{tabular}{|c|c|c|c|c|c|c|c|c|}
\hline \multirow{2}{*}{$\begin{array}{l}\text { Cost of control } \\
(\$ / \text { ha })^{a}\end{array}$} & \multirow{2}{*}{$\begin{array}{l}\text { Market price } \\
\quad(\$ / \text { ton })^{b}\end{array}$} & \multirow{2}{*}{$\begin{array}{l}\text { Yield potential } \\
\quad(\text { ton } / \text { ha })^{c}\end{array}$} & \multirow{2}{*}{$\begin{array}{l}\text { EIL: cumulative } \\
\text { aphid-days }\end{array}$} & \multirow{2}{*}{$\begin{array}{l}\text { EIL: aphids } \\
\text { per plant }\end{array}$} & \multicolumn{4}{|c|}{ ET with different lead times (d): } \\
\hline & & & & & 1 & 3 & 5 & 7 \\
\hline \multirow[t]{12}{*}{16.41} & \multirow[t]{4}{*}{202.09} & 2.02 & 5,649 & 684 & 601 & 465 & 359 & 278 \\
\hline & & 2.69 & 4,188 & 507 & 446 & 345 & 266 & 206 \\
\hline & & 3.36 & 3,309 & 401 & 353 & 272 & 211 & 163 \\
\hline & & 4.04 & 2,715 & 329 & 289 & 224 & 173 & 134 \\
\hline & \multirow{4}{*}{220.46} & 2.02 & 5,160 & 625 & 549 & 425 & 328 & 254 \\
\hline & & 2.69 & 3,821 & 463 & 407 & 314 & 243 & 188 \\
\hline & & 3.36 & 3,015 & 366 & 321 & 248 & 192 & 148 \\
\hline & & 4.04 & 2,471 & 300 & 263 & 204 & 157 & 122 \\
\hline & \multirow{4}{*}{238.83} & 2.02 & 4,747 & 575 & 505 & 391 & 302 & 233 \\
\hline & & 2.69 & 3,510 & 425 & 374 & 289 & 223 & 173 \\
\hline & & 3.36 & 2,766 & 335 & 295 & 228 & 176 & 136 \\
\hline & & 4.04 & 2,264 & 275 & 241 & 187 & 144 & 111 \\
\hline \multirow{12}{*}{24.51} & \multirow[t]{4}{*}{202.09} & 2.02 & 8,546 & 1,035 & 909 & 703 & 543 & 420 \\
\hline & & 2.69 & 6,363 & 771 & 677 & 523 & 404 & 313 \\
\hline & & 3.36 & 5,051 & 612 & 538 & 416 & 321 & 248 \\
\hline & & 4.04 & 4,164 & 504 & 443 & 343 & 265 & 205 \\
\hline & \multirow[t]{4}{*}{220.46} & 2.02 & 7,816 & 946 & 832 & 643 & 497 & 384 \\
\hline & & 2.69 & 5,815 & 704 & 619 & 478 & 370 & 286 \\
\hline & & 3.36 & 4,611 & 559 & 491 & 379 & 293 & 227 \\
\hline & & 4.04 & 3,798 & 460 & 405 & 313 & 242 & 187 \\
\hline & \multirow[t]{4}{*}{238.83} & 2.02 & 7,198 & 871 & 766 & 592 & 457 & 353 \\
\hline & & 2.69 & 5,350 & 648 & 570 & 440 & 340 & 263 \\
\hline & & 3.36 & 4,240 & 514 & 452 & 349 & 270 & 208 \\
\hline & & 4.04 & 3,489 & 423 & 372 & 287 & 222 & 172 \\
\hline \multirow[t]{13}{*}{32.94} & \multirow{4}{*}{202.09} & 2.02 & 11,561 & 1,399 & 1,230 & 950 & 734 & 567 \\
\hline & & 2.69 & 8,627 & 1,044 & 918 & 709 & 548 & 424 \\
\hline & & 3.36 & 6,863 & 831 & 730 & 564 & 436 & 337 \\
\hline & & 4.04 & 5,671 & 687 & 604 & 467 & 360 & 279 \\
\hline & \multirow{4}{*}{220.46} & 2.02 & 9,696 & 1,174 & $\begin{array}{l}1,032 \\
\end{array}$ & 797 & 616 & 476 \\
\hline & & 2.69 & 7,890 & 955 & 840 & 649 & 501 & 387 \\
\hline & & 3.36 & 6,273 & 760 & 668 & 516 & 399 & 308 \\
\hline & & 4.04 & 5,180 & 627 & 552 & 426 & 329 & 254 \\
\hline & \multirow{5}{*}{238.83} & 2.02 & 8,933 & 1,081 & 951 & 735 & 568 & 439 \\
\hline & & 2.69 & 7,266 & 880 & 773 & 598 & 462 & 357 \\
\hline & & 3.36 & 5,773 & 699 & 615 & 475 & 367 & 284 \\
\hline & & 4.04 & 4,765 & 577 & 507 & 392 & 303 & 234 \\
\hline & & Mean & 5,563 & 674 & 592 & 458 & 354 & 273 \\
\hline
\end{tabular}

${ }^{a}$ Cost of control in $\$ /$ ac equivalents are $\$ 6.64,9.92$, and 13.33 , respectively.

${ }^{b}$ Market value estimates in $\$ /$ bu equivalents are $\$ 5.50,6.00$, and 6.50 , respectively.

${ }^{b}$ Yield expectations in bu/ac equivalents are $30,40,50$ and 60 , respectively.

mature soybean fields without a nonplanted tram line to apply insecticides (Beuerlein et al. 2005). Such mechanical losses caused by ground application are not included in our calculated ET. Conversely, availability of generic insecticides could reduce control costs and seed treatment does seem to slow the early season population growth rate of soybean aphid. However, to obtain maximum economic yield during aphid outbreak years, a foliar application may still be warranted in fields where seed treatments were used (McCornack and Ragsdale 2006). Here, we focused on the major economic variables when calculating a range of ETs and EILs.

Aphid Population Densities and Associated Yields. An example of the graphical relationship between aphids per plant and CAD from one location-year is presented in Fig. 1A and B, respectively. It is difficult to discern the population trends among various target aphid densities (Fig. 1A) when plotting aphid density on a per plant basis. Differences are apparent when converting from aphids per plant to a CAD scale (Fig. 1B). When an individual CAD line remains parallel with the $x$-axis (Fig. 1B), this represents few or no aphids per plant were found during subsequent sampling periods.

Initial soybean aphid colonization across all location-years occurred between 1 June and 23 July, corresponding with plant growth stages V1 (first trifoliolate) to reproductive stage $\mathrm{R} 2$ (multiple flowers). Mean peak aphid density and standard error $( \pm$ SEM) in untreated control plots for all location-years was 1,262 \pm 351 aphids per plant with peak densities ranging from 17 to 4,275 aphids per plant. Peak aphid densities typically occurred between late July and late August (Fig. 2) when soybeans were in reproductive growth stages R3 (pod formation) through R5 (full size pod). Mean CAD across all location-years was $10,573 \pm 1,338$ and ranged from 1 to 70,771 across all target aphid densities (Fig. 2). Mean population growth rate, $r$, across all location-years was $0.127 / \mathrm{d} \pm$ 0.014 or $\lambda=\mathrm{e}^{r}=1.138 / \mathrm{d} \pm 0.016$ with $R^{2}$ values for all location-years ranging from 0.715 to 0.995 (Table 1). Recall, $r$ was calculated using transformed weekly aphid counts beginning when sampling data showed 

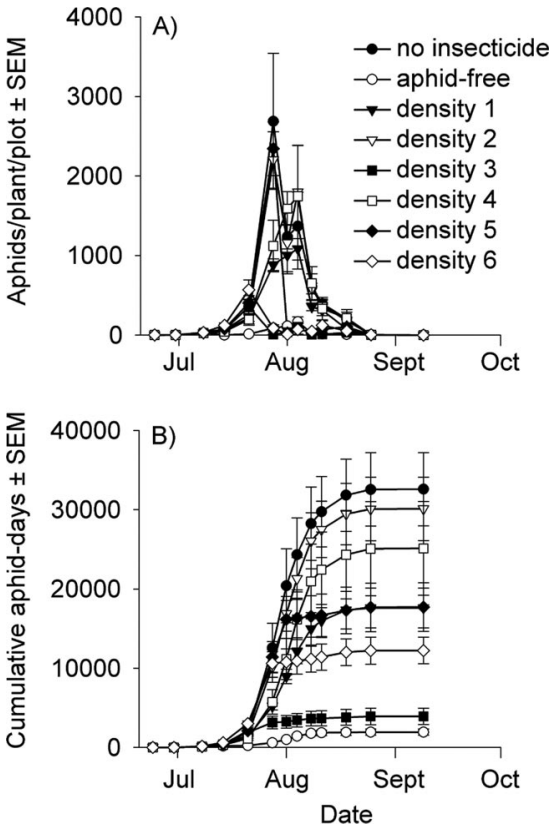

Fig. 1. Soybean aphid population curves expressed as aphids per plant (A) and CAD (i.e., one aphid per plant per day equals one aphid-day) (B) over multiple sampling times in one location-year (Rosemount, MN, in 2003).

$>80 \%$ of plants were infested and ended when peak aphid density was attained. Average aphid density at $80 \%$ infestation was $21 \pm 7$ aphids per plant in the untreated controls. From the estimates of $r$ we calculated the average doubling time in days using the equation $\ln (2) / r$ (Table 1) and for all 19 locationyears the average doubling time for field populations was $6.8 \pm 0.8 \mathrm{~d}$ with observed doubling times ranging from 2.7 to $13.4 \mathrm{~d}$. McCornack et al. (2004) estimated intrinsic rate of increase under controlled conditions at various constant temperatures and values ranged from $-0.383-0.474$ at constant 35 and $20^{\circ} \mathrm{C}$, respectively. Their estimate of population doubling time at the optimal temperature of $27.8^{\circ} \mathrm{C}$ was calculated as $1.3 \mathrm{~d}$. These population growth estimates by McCornack et al. (2004) represent the biotic potential for soybean aphid in absence of environmental resistance. Here, we estimated growth rates $(r)$ of field populations which accounted for impact of natural enemies, weather, increase or loss of aphids from winged aphids (immigration and emigration), and other factors (van den Berg et al. 1997, Li et al. 2004, Costamagna and Landis 2006).

Others have calculated an ET for soybean aphid by using laboratory-derived intrinsic rate of increase $(\mathrm{Ol}$ son and Badibanga 2005a) or from population growth rates of caged field populations (Catangui 2006), which excluded natural enemies and other events such as rainfall that can significantly reduce population growth rates (Dixon 1976). Setting an ET too low by using population doubling times based on laboratory-derived reproductive rates or those that occur in the absence of natural enemies will result in too many fields requiring treatment without realizing an economic benefit. In other work (McCornack and Ragsdale 2006), treating soybean aphid populations that did not exceed the ET calculated here resulted in accrued control costs without a measurable yield benefit, thus a net loss to producers. For other aphid pests, frequent application of insecticide has resulted in high levels of insecticide resistance (Radcliffe and Ragsdale 2002, Wang et al. 2002). Care must always be exercised when dealing with aphids that reproduce parthenogenically during the growing season to avoid repeated insecticide applications that could lead to resistance.

Across all 19 location-years in plots where the target aphid density was $0 \mathrm{CAD}$, the observed CAD averaged $1,567 \pm 446$. Most of the CAD in these plots occurred during vegetative growth stages V1 to V8, and subsequent insecticide application kept aphid density low during the reproductive stages. Myers et al. (2005) showed that application of insecticides to vegetative growth stages for soybean aphid control had no measurable impact on yield, so any plant injury caused by aphids feeding during vegetative growth stage in this study was likely immeasurable. At the time of the first insecticide application to the plots with a target aphid density of 0 CAD, mean aphid density on a per plant basis was $17 \pm 3$ aphids per plant. Mean aphid density on a per plant basis after application of lambda-cyhalothrin was $3 \pm 1$ and ranged from 0 to 20 . Only in four of the 19 location-years (two locations in Minnesota in 2003 and two locations in Iowa in 2005) was a second insecticide application made to plots with a target aphid density of $0 \mathrm{CAD}$, and in two location-years (one each in Iowa and Michigan in 2005), a third insecticide application was needed. In these six location-years where additional insecticide application were deemed necessary, mean aphid density at the time of the second application was $77 \pm 13$ and for the third application mean aphid density was $12 \pm 9$ aphids per plant. We intentionally avoided more frequent application of insecticides, e.g., weekly, to plots where the target aphid density was 0 CAD. By applying insecticides too frequently, especially pyrethroids, twospotted spider mite, Tetranychus urticae Koch, outbreaks can occur (Yang et al. 2002, Steffey et al. 2006), which would confound the yield loss relationship. No spider mite outbreaks were noted from any of the 19 location-years. In all remaining location-years (13 of 19) only a single application was needed to control aphids and population growth did not increase after an insecticide application.

Because the experiment was conducted in six states where the soybean maturity group typically planted in each state ranged from group 00 to group 3, we were unable to directly compare yield losses among locations. Average yield in plots that had the fewest CAD was $3.38 \pm 0.23 \mathrm{ton} / \mathrm{ha}(50.2 \pm 3.4 \mathrm{bu} / \mathrm{acre})$ and ranged from 1.96 to $4.8 \mathrm{ton} / \mathrm{ha}(29.2-71.4 \mathrm{bu} / \mathrm{acre})$. Because weather conditions, soil type, maturity group, and other agronomic factors were highly variable among location-years, we measured the change in 


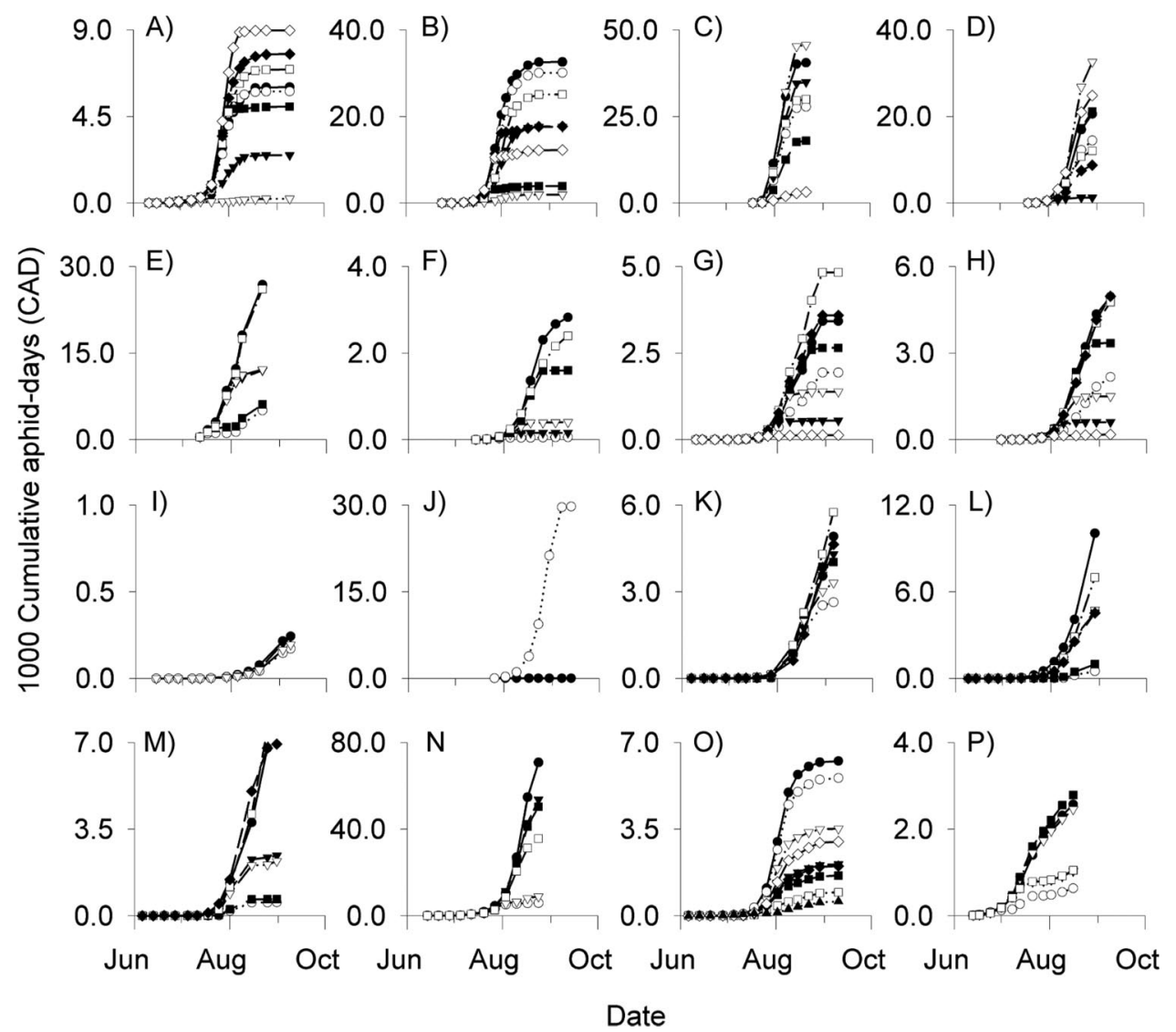

Fig. 2. Cumulative aphid-day curves for all 19 location-years during the 2003, 2004, and 2005 seasons. (A-E) Minnesota 2003. (G-I) Minnesota 2004. (O) Minnesota 2005. (F) North Dakota 2004. (J) Nebraska 2004. (K-M) Iowa 2005 (each panel for Iowa represents two planting dates at each of three unique locations for a total of six location-years). (N) Michigan 2005. (P) Wisconsin 2005. Symbols represent different target CAD densities within each location-year.

yield (percentage of maximum yield) as aphid-days accumulated. This allowed us to directly compare data from all 19 location-years. Within a single locationyear we measured yield where the target aphid density was $0 \mathrm{CAD}$ and designated this yield as the maximum yield $(100 \%)$ obtainable. We then measured the percentage yield loss relative to this maximum yield in treatments where the target aphid density was $>0$ CAD. It is not possible to totally eliminate aphids even with repeated insecticide application, but the goal was to keep aphids as low as possible in the treatment where the target aphid density was $0 \mathrm{CAD}$ without flaring secondary pests. For these 19 location-years, there was no evidence of bean leaf beetle, Cerotoma trifurcata (Forster), feeding or injury caused from other defoliating insects reported, so yield losses measured here are from plant damage solely attributed to soybean aphid feeding injury.

We used linear regression to relate relative yield obtained in the plots where the target aphid density was $0 \mathrm{CAD}$ to relative yield in plots where aphids were allowed to accrue higher CAD. We observed that CAD was negatively correlated with yield $(F=212.09$; $\left.\mathrm{df}=1,103 ; P<0.0001 ; R^{2}=0.665\right)$ (Fig. 3). In addition, the y-intercept $[y=0.9985-0.0688(\mathrm{CAD})]$ from the linear regression passed through $100 \%$ of the proportion maximum yield (Fig. 2), indicating that the yield loss relationship was best explained by the linear regression and that when CAD were near zero yield

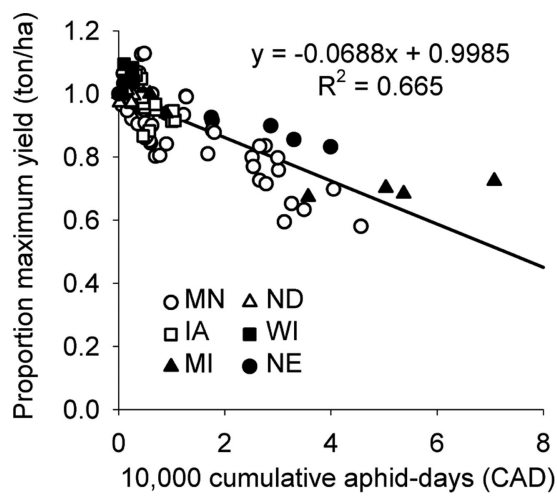

Fig. 3. Percentage of maximum yield comparing plots with the target aphid density of 0 CAD to plots with target aphid densities $>0$ CAD for all 19 location-years $(n=116)$. 
observed was not different from the yield potential. The $95 \%$ confidence interval (CI) for the y-intercept was $0.984-1.016$, and, therefore not significantly different from 1.0 at $\alpha=0.05$. Yield (tons per hectare) was reduced by $6.88 \%$ (95\% CI was $5.94-7.82 \%$ ) for every 10,000 aphid-days accumulated (Fig. 3).

As an example of how long it takes to accumulate $\approx 5,563$ aphid-days, the mean EIL listed in Table 2, for a 7-d lead time, we provide the following hypothetical calculation. If the starting aphid population was one aphid per plant $(a)$ and we used the lowest and highest EILs from Table 2 of 275 and 1,399 for the values of $(l)$ in equation 5 and the mean value for $\lambda$ of 1.138 (Table 1 ), we can solve for the number of $\mathrm{d}(t)$ it will take this aphid population to reach either EIL. For the EIL of 275 , it will take $43 \mathrm{~d}$ and for the EIL of 1,399, it will take $56 \mathrm{~d}$ or $\approx 6-8 \mathrm{wk}$ for aphids to go from one aphid per plant until they reach the EIL.

A more relevant question might be how long will a starting population of 100 aphids per plant take to reach the EIL? First, we must use equation 3 to estimate how many CAD occurred between 1 and 100 aphids per plant. Solving for $s$ in equation 3 , there were $817 \mathrm{CAD}$, and this value is subtracted from the average EIL in CAD (Table 2) of 5,563, leaving 4,746 CAD remaining. Using this remaining value in equation 4 , we can solve for $l$, which is 576 aphids per plant. The number of days it will take to go from 100 aphids per plant to 576 aphids per plant can be estimated using equation 5 by using the value of $\lambda$ as 1.138 (Table 1 ), which when solved for $(t)$ in equation 5 , the EIL will be reached in $14 \mathrm{~d}$.

In general, as aphid populations increase, the more accurate the prediction of when the EIL will be reached. To predict when the aphid density will reach the EIL starting with a density of one aphid per plant is nearly impossible. There is too much time $(6-8 \mathrm{wk})$ where weather, natural enemies, disease, host plant quality, and other factors could influence the aphid population growth rate. In the examples above, only $15 \%$ of the CAD needed to reach the EIL were realized when aphid populations were between 1 and 100 aphids per plant. It would take $\approx 4-6$ wk for aphid densities to reach 100 aphids per plant. Conversely, $85 \%$ of the CAD needed to achieve the EIL occurred after the aphid density reached 100 per plant and an estimated additional $14 \mathrm{~d}$ at the average aphid population growth rates to reach the EIL once aphid densities reached 100 per plant.

Economic Threshold. Although we estimated the yield response of soybean injury to soybean aphid feeding using CAD as a measure of season-long exposure of plants to soybean aphid, we suggest that this method will not be as useful to most producers or their advisors as an ET based on aphid density per plant. To calculate CAD requires regular and multiple visits to the field. If sampling occurs less frequently or at irregular intervals that greatly exceed $7 \mathrm{~d}$, such estimates of CAD are less reliable. Therefore, we converted the EIL based on CAD to the average aphid density per plant using the average, field-based, finite population doubling time of $6.8 \mathrm{~d}$ (Table 1 ) to calcu- late the aphid density on a per plant basis that would occur at selected intervals before reaching the EIL. We arbitrarily selected $1,3,5$, and $7 \mathrm{~d}$ before reaching the EIL, and we estimated the ET in terms of aphids per plant (Table 2). The mean ET across all yield expectations, market values, and control costs presented in Table 2 with a lead time of $7 \mathrm{~d}$ was $273 \pm 38$ (95\% CI) aphids per plant. The corresponding EIL was $674 \pm 95(95 \%$ CI $)$ aphids per plant.

In 18 of the 19 location-years, peak aphid abundance was reached between growth stages R3 to R5; at the time of $80 \%$ infestation, when measurement of aphid population growth rates were initiated, plots were in plant growth stages R1 (first flower) to R4 (intermediate pod formation). Only one location-year (Nebraska 2004) had peak aphid abundance that occurred during soybean growth stage R6 (full size green seed). Although a significant yield loss was measured at the Nebraska 2004 location, Ostlie (2001) showed with on-farm strip trials that producers were less likely to achieve an economic benefit by treating aphid populations when plants were in reproductive stage $\mathrm{R} 6$ or later. With the majority of the location-years having peak aphid abundance that exceeded $80 \%$ infestation as early as R1 and the ET exceeded at the latest during R5, the ET developed here using a $7 \mathrm{~d}$ lead time is valid between R1 to R5. More research is needed to estimate a valid threshold for growth stages after R5. Our data suggest that an ET for R6 and later growth stages will exceed 273 aphids per plant, but we have too few data sets to accurately estimate the ET during $\mathrm{R} 6$ and no data for aphid populations that might peak during $\mathrm{R} 7$.

These data collected from 19 location-years over a 3 -yr period and in six states represent a wide range of soybean production systems and aphid infestations with respect to the period between initial colonization and peak population density (Fig. 2). EILs and the calculated ET for any pest needs to be dynamic and respond to changing conditions in market value, expected yield, and variable control costs (Barrigossi et al. 2003). Table 2 covers a wide variation in the associated costs and market values using the yield-loss regression equation (Fig. 3) to calculate an ET. The aphid population data we used to derive the EIL and corresponding ET were from field populations that increased in the presence of natural enemies (predators, parasites, and pathogens), adverse weather conditions (heavy rainfall, drought stress, and low and high temperatures that are beyond optimal ranges), and plant growth stages. We made the assumption that all varieties used in the study were susceptible to soybean aphid, because no aphid-resistant soybean variety is currently available to growers in the North Central region ( $\mathrm{Li}$ et al. 2004). In the future, soybean varieties will be developed and released that are resistant or tolerant to soybean aphid. Equally likely is the release and establishment of classical biological control agents along with a greater understanding of the value of native natural enemies. This ET will therefore need to be modified to account for such changes to the soybean production system. For example, re- 
sistant soybean varieties may delay aphid doubling times and EILs for tolerant varieties would be higher than our reported values. Also, new yield loss relationships will need to be estimated for resistant or tolerant soybean varieties.

If the maximum soybean yield and highest soybean price is expected and the lowest possible treatment cost is assumed, the ET with a 7-d lead time is 111 aphids per plant with a corresponding EIL of 275 (Table 2). However, caution must be used in interpreting these calculated thresholds that fall well below the average ET of 273 and EIL of 674 aphids per plant. The GT for the lowest treatment cost is approximately the value of $0.07 \mathrm{ton} / \mathrm{ha}(\approx 1 \mathrm{bu} / \mathrm{acre})$, and significant yield differences this small were not measurable from any of our 19 location-years. Essentially, ET and EIL values can be calculated using the yieldloss equation from this study (Fig. 3), but we consider these low ET values impractical, and the yield loss associated with the corresponding EILs is immeasurable. The value of Table 2 is to demonstrate the relative sensitivity of the variables used in the EIL and ET calculations.

The ET calculated from this study of $273 \pm 38$ (95\% CI) overlaps a consensus action threshold that was promoted after a widespread soybean aphid outbreak that occurred in 2003 of 250 aphids per plant with $>80 \%$ of plants being aphid-infested (NCSRP 2006). This action threshold was derived from a subset of location-years included in this study (six of the 19 location-years). In a recent survey, $66 \%$ of respondents correctly identified, this action threshold and $84 \%$ indicated that scouting for aphids was critical for effective aphid management (Olson and Badibanga $2005 \mathrm{~b}$ ). The long-term benefits of delaying treatment for as long as practical are far reaching. Some natural enemies in soybean are known to follow soybean aphid to its principal overwintering host, common buckthorn, Rhamnus cathartica L., (Yoo et al. 2005), and these predators and pathogens (Nielsen and Hajek 2005) continue to reduce aphid populations on the overwintering host well past soybean harvest. Conserving soybean aphid natural enemies is of utmost importance and this ET, if widely adopted, will help preserve natural enemies on a landscape level and provide producers the means to make decisions that avoid treating subeconomic aphid populations.

\section{Acknowledgments}

We thank the North Central Soybean Research Program, the Iowa Soybean Association, the Minnesota Soybean Research and Promotion Council, the North Dakota Soybean Council, the University of Minnesota Rapid Agricultural Response Fund, and the Agricultural Experiment Stations in Indiana, Iowa, Michigan, Minnesota, Nebraska, North Dakota, and Wisconsin for financial assistance and support for fieldwork conducted in the participating states. We also thank the many individuals in the six states that helped collect data, count aphids, manage field plots and assisted in all aspects of this 3-yr study.

\section{References Cited}

Barrigossi, J.A.F., G. L. Hein, and L. G. Higley. 2003. Economic injury level and sequential sampling plans for Mexican bean beetle (Coleoptera: Coccinellidae) on dry beans. J. Econ. Entomol. 96: 1160-1167.

Beuerlein, J. E., R. B. Hammond, A. E. Dorrance, and D. R. Mills. 2005. Using Skip rows for soybean pest management increases profit. The Ohio State University, Agonomic Crops Network. (http://agcrops.osu.edu/ soybean/SkipRow5\%20October\%202005.pdf).

Catangui, M. A. 2006. Economic threshold of the soybean aphid, A. glycines, in South Dakota. (http://plantsci. sdstate.edu/ent/entpubs/sa economic threshold.htm).

Clark, A. J., and K. L. Perry. 2002. Transmissibility of field isolates of soybean viruses by Aphis glycines. Plant Dis. 86: 1219-1222.

Costamagna, A. C., and D. A. Landis. 2006. Predators exert top-down control of soybean aphid across a gradient of agricultural management systems. Ecol. Appl. 16: 16191628.

Davis, J. A., E. B. Radcliffe, and D. W. Ragsdale. 2005. Soybean aphid, Aphis glycines Matsumura, a new vector of Potato Virus $Y$ in potato. Am. J. Potato Res. 81: 101-105.

DiFonzo, C. D., D. W. Ragsdale, E. B. Radcliffe, N. C. Gudmestad, and G. A. Secor. 1996. Crop borders reduce potato virus Y incidence in seed potato. Ann. Appl. Biol. 129: $289-302$

Dixon, A.F.G. 1976. Timing of egg hatch and viability of the sycamore aphid, Drepanosiphum platanoidis (Schr.), at bud burst of sycamore. J. Anim. Ecol. 45: 593-603.

Dobbins, C. L., S. Wilson, and Z. Cain. 2004. Agricultural economics: Indiana custom rates 2004, pp 1-3. Purdue University Extension Publication EC-130-W. Purdue University, West Lafayette, IN.

Edwards, W., and D. Smith. 2005. Ag decision maker: 2005 Iowa farm custom rate survey, pp 1-3. Iowa State University Extension, Ames, IA. (www.extension.iastate. edu/agdm).

Fehr, W. R., and C. E. Caviness. 1977. Stages of soybean development. Iowa State University Cooperative Extension Service Special Rep. 80. Iowa State University, Ames, IA.

Fox, T. B., D. A. Landis, F. F. Cardoso, and C. D. DiFonzo. 2004. Predators suppress Aphis glycines Matsumura population growth in soybean. Environ. Entomol. 33: 608618.

Hanafi, A., E. B. Radcliffe, and D. W. Ragsdale. 1989. Spread and control of potato leafroll virus in Minnesota. J. Econ. Entomol. 82: 1201-1206.

Hodgson, E. W., R. L. Koch, and D. W. Ragsdale. 2005. Pan trapping for soybean aphid (Homoptera: Aphididae) in Minnesota soybean. J. Entomol. Sci. 40: 409-419.

Karley, A. J., W. E. Parker, J. W. Pitchford, and A. E. Douglas. 2004. The mid-season crash in aphid populations: why and how does it occur? Ecol. Entomol 29: 383-388.

Lazarus, W., and R. Selley. 2005. Farm machinery economic cost estimates for late 2005, pp 1-12. University of Minnesota Extension Service, University of Minnesota, St. Paul, MN. (http://www.apec.umn.edu/faculty/ wlazarus/mf2005late.pdf).

Li, Y., C. B. Hill, and G. L. Hartman. 2004. Effect of three resistant soybean genotypes on the fecundity, mortality, and maturation, of soybean aphid (Homoptera: Aphididae). J. Econ. Entomol. 97: 235-239.

Macedo, T. B., C. S. Bastos, L. G. Higley, K. R. Ostlie, and S. Madhavan. 2003. Photosynthetic responses of soybean to soybean aphid (Homoptera: Aphididae) injury. J. Econ. Entomol. 96: 188-193. 
McCornack, B. P., and D. W. Ragsdale. 2006. Efficacy of thiamethoxam to suppress soybean aphid populations in Minnesota soybean. J. Crop Manage. (http:// dx.doi.org/ 10.1094/CM-2006-0915-01-RS).

McCornack, B., D. W. Ragsdale, and R. C. Venette. 2004. Demography of soybean aphid (Homoptera: Aphididae) at summer temperatures. J. Econ. Entomol. 97: 854-861.

Myers, S. W., D. B. Hogg, and J. L. Wedberg. 2005. Determining the optimal timing of foliar insecticide applications for control of soybean aphid (Hemiptera: Aphididae) on soybean. J. Econ. Entomol. 98: 2006-2012.

[NASS] National Agricultural Statistics Service. 2006. United States Department of Agriculture (http://www. nass.usda.gov/index.asp).

[NCSRP] North Central Soybean Research Program, Plant Health Initiative. 2006. Soybean aphid management. (http://www.planthealth.info/aphids mgmnt.htm).

Nielsen, C., and A. E. Hajek. 2005. Control of invasive soybean aphid, Aphis glycines (Hemiptera: Aphididae), populations by existing natural enemies in New York State, with emphasis on entomopathogenic fungi. Environ. Entomol. 34: 1036-1047.

Olson, K. and T. Badibanga. 2005a. A bioeconomic model of the soybean aphid treatment decision in soybeans. Selected paper, American Agricultural Economics Association Annual Meeting, 24-27 July 2005, Providence, RI. (http:// agecon.lib.umn.edu/cgi-bin/pdf view.pl?paperid=16358).

Olson, K., and T. Badibanga. 2005b. Farmers' awareness and case of IPM for soybean aphid control: results from the 2005 survey. Staff Paper P05-13. (http://agecon.lib.umn.edu/ cgi-bin/pdf view.pl?paperid=19374\&ftype $=$. pdf).

Ostlie, K. [ed.]. 2001. Soybean aphid reduces yields: harvest results from insecticide strip trials. University of Minnesota, St. Paul, MN. (http://www.soybeans.umn. edu/crop/insects/aphid/studyresults.htm).

Pedigo, L. P., S. H. Hutchins, and L. G. Higley. 1986. Economic injury levels in theory and practice. Annu. Rev. Entomol. 31: 341-368.

Radcliffe, E. B., and D. W. Ragsdale. 2002. Aphid transmitted potato viruses: the importance of understanding vector biology. Am. J. Pot. Res. 79: 353-386.
Ragsdale, D. W., D. J. Voegtlin, and R. J. O’Neil. 2004. Soybean aphid biology in North America. Ann. Entomol. Soc. Am. 97: 204-208.

SAS Institute. 2001. PROC user's manual, version 6th ed SAS Institute, Cary, NC.

Steffey, K., M. Gray, R. Estes, J. Schroeder, D. Bakken, D. Schaefer, and G. Roskamp. 2006. Twospotted spider mites: case study in soybean pest management. Illinois Crop Protection Technology Conference, 2006 Proceedings. (http://www.ipm.uiuc.edu/conferences/cptc/ proceedings.pdf)

van den Berg, H., D. Ancaza, A. Mamad, R. Rusli, H. A Widayanto, H. B. Wirasto, and I. Yully. 1997. Evaluating the role of predation in population fluctuations of the soybean aphid Aphis glycines in farmers' field in Indonesia. J. Appl. Ecol. 34: 971-984.

Wang, X. B., Y. H. Fang, S. Z. Lin, L. R. Zhang, and H. D. Wang. 1994. A study on the damage and economic threshold of the soybean aphid at the seedling stage. Plant Prot. 20: 12-13.

Wang, K. Y., T. X. Liu, C. H. Yu, X. Y. Jiang, and M. Q. Yi. 2002. Resistance of Aphis gossypii (Homoptera: Aphididae) to fenvalerate and imidacloprid and activities of detoxification enzymes on cotton and cucumber. J. Econ. Entomol. 95: 407-413.

[WASS] Wisconsin Agricultural Statistics Service. 2004. Wisconsin's 2004 custom rate guide (http://www.nass. usda.gov/Statistics by State/Wisconsin/Publications/ custom_rate_2004.pdf).

Yang, X., L. L. Buschman, K. Y. Zhu, and D. C. Margolies. 2002. Susceptibility and detoxifying enzyme activity in two spider mite species (Acari: Tetranychidae) after selection with three insecticides. J. Econ. Entomol. 95: 399 406.

Yoo, H.J.S., R. J. O’Neil, D. J. Voegtlin, and W. R Graves. 2005. Host plant suitability of Rhamnaceae for soybean aphid (Homoptera: Aphididae). Ann. Entomol. Soc. Am. 98: 926-930.

Received 7 November 2006; accepted 16 April 2007. 